\title{
Study on the Production of Protease and Standardization of Optimal Conditions in Leather Industry
}

\author{
S. Vasantham*, S. Chithra
}

Department of Microbiology, Sri Sarada Niketan College of Science for Women, Karur, Tamil Nadu, India

| Received: 27.04.2020| Accepted: 07.05.2020 | Published: 16.05 .2020

*Corresponding author: S. Vasantham

Abstract Original Research Article

The aspect of this work is to produce extracellular protease enzyme which could be applicable in Leather industries worldwide. Protease is an extra cellular proteolytic enzyme that hydrolyzes proteins into amino acids. The isolated strain with high protease yields was optimized with respect to growth media, inoculum concentration and agitation speed. Maximum protease production occurred in Wheat flour Skim milk (WS) medium containing Wheat flour, (1\%w/v); Skim milk powder, $(1 \% \mathrm{w} / \mathrm{v}) ; \mathrm{NaCl}(0.5 \% \mathrm{w} / \mathrm{v})$, and initial inoculum concentration of $6 \%(\mathrm{v} / \mathrm{v})$ at $140 \mathrm{rpm}$ shaking conditions and at 72 hours. The optimum $\mathrm{pH}$ and temperature for protease activity was assayed using casein as a substrate dissolved in buffers with $\mathrm{pH}$ ranging from 4.0 to 10.0 at different temperatures from $25^{\circ} \mathrm{C}$ to $75^{\circ} \mathrm{C}$. The crude protease showed maximum enzyme activity at pH 9.0 in $0.1 \mathrm{M}$ Carbonate-bicarbonate buffer at $40^{\circ} \mathrm{C}$. This activity was considerably maintained for 1 hour. The enzyme exhibited remarkable stability in the presence of SDS and Triton X-100. The application study suggested that the crude enzyme could be effectively used to remove hair from goat skin indicating its potential in Leather processing industry.

Keywords: Protease enzyme, Wheat flour skim milk medium, crude enzyme, Alkaline protease, dehairing, batting, Optimisation.

Copyright @ 2020: This is an open-access article distributed under the terms of the Creative Commons Attribution license which permits unrestricted use, distribution, and reproduction in any medium for non-commercial use (NonCommercial, or CC-BY-NC) provided the original author and source are credited

\section{INTRODUCTION}

Proteolytic enzymes are capable of hydrolyzing peptide bonds and are called as peptidases, proteases and proteinases. These enzymes are one of the most important groups of industrial enzymes and accounts for approximately $60 \%$ in the total enzymes sale and can be produced from plants, animals and microorganisms [1]. Some micro organisms are the best source of proteolytic enzyme production because of the high yield in a short time with in a less space $[2,3]$.

These enzymes are classified into various types based on their activity under acidic, neutral, and alkaline conditions. Alkaline proteases are playing an important role in the manufacture of detergents, food, pharmaceuticals and leather industries [4]. In the leather industry, alkaline proteases with elastolytic and keratinolytic activity can be used in the soaking, dehairing, and batting stages of preparing skins and hides. The enzymatic treatment speed up the processing of dehairing, because the alkaline conditions enable the swelling of hair roots and allows easy removal of the hair [5].
The Leather industry is the major source of industrial pollution problem in the country. The pollution causing chemicals, being lime, sodium sulphate, salt, solvents, etc [6]. In order to overcome this problem, biological sources such as proteolytic enzymes are used. In this study protease producing microorganism was isolated and the proteolytic activity was subjected to a range of biochemical tests. The maximum production of protease was analysed under various media composition, inoculum size, agitation speed, $\mathrm{pH}$, and temperature [7]. After that the stability and scale-up studies were carried out to improve the application of the enzyme in dehairing process. This opens wide scope for further research to identify novel agents to increase the yield of this protease enzyme. In future molecular studies could be open to improve the strain and their application in Leather industries.

\section{MATERIALS AND METHOD}

Skim milk powder, Wheat flour, Starch, Maltose, Glucose, Casein, Sodium Dodecyl Sulfate, Acrylamide, $\beta$ - mercaptoethanol, other media components were products of Sigma-Aldrich, St Louis, MO, USA. All other chemicals were used from Fisher Scientific (Waltham, MA, USA) for analytical work and 
S. Vasantham \& S. Chithra., Sch Acad J Biosci, May., 2020; 8(5): 118-126

stability studies. Whatman filter paper No.1 was used in protease assay.

\section{Isolation and Screening}

The protease producing organism was isolated from the serially diluted $10^{-7}$ dilution of mixture culture from Central Leather Research Institute, Adayar, Chennai by inoculating them onto the skim milk agar plates containing skim milk powder $(3 \% \mathrm{w} / \mathrm{v})$, agar $(2.5 \% \mathrm{w} / \mathrm{v})$. Appearance of clear zones around isolated colonies formed by hydrolysis of skim milk was used as a identification of protease enzyme producer $[8,9]$. The resulting isolated colonies were subcultured onto skim milk agar plates and nutrient agar slants, grown at $37^{\circ} \mathrm{C}$ for 24 hours and maintained at $4^{0} \mathrm{C}$ for further studies. Identification of organism was made by a range of biochemical tests for identification.

\section{Protease enzyme production and protease assay}

Pre-inoculum was prepared by inoculating from the stock culture into the $50 \mathrm{ml}$ of nutrient broth and incubating at $37^{\circ} \mathrm{C}$ for 24 hour on a rotary shaker at 200 rpm. Quantitative analysis of protease activity was performed according to modified Anson's method using casein as a substrate. The substrate solution was added to the enzyme solution and the mixture was incubated at $37^{0} \mathrm{C}$ for $20 \mathrm{~min}$. The reaction was stopped by addition of Trichloroacetic acid (TCA) solution followed by filtration through Whatman filter paper No.1. A control was run in which the Trichloroacetic acid was added before the enzyme solution. All the determinants and controls were run in duplicate and averages were used. The Trichloroacetic acid (TCA) soluble protein fraction released from casein by the hydrolytic action of the enzyme was estimated by Lowry et al., method [10]. One unit of protease activity (U) is defined as the amount of enzyme required to release one microgram of tyrosine in one minute under the conditions described below.

\begin{tabular}{|c|c|c|}
\hline Reagent & Test & Control \\
\hline Enzyme & $0.1 \mathrm{ml}$ & $0.1 \mathrm{ml}$ \\
\hline Buffer (pH 9.2) & $0.9 \mathrm{ml}$ & $0.9 \mathrm{ml}$ \\
\hline TCA $(10 \%)$ & -- & $3 \mathrm{ml}$ \\
\hline Casein $(1 \%)$ & $1 \mathrm{ml}$ & $1 \mathrm{ml}$ \\
\hline \multicolumn{3}{|c|}{ Incubate for 20 minutes at $37^{\circ} \mathrm{C}$} \\
\hline TCA $(10 \%)$ & $3 \mathrm{ml}$ & -- \\
\hline
\end{tabular}

\begin{tabular}{|l|l|l|}
\hline Reagent & Test & Blank \\
\hline Filtrate & $0.1 \mathrm{ml}$ & $0.1 \mathrm{ml}$ \\
\hline Distilled water & $0.9 \mathrm{ml}$ & $0.9 \mathrm{ml}$ \\
\hline $\mathrm{CuSO}_{4}$ & $200 \mu \mathrm{l}$ & $200 \mu \mathrm{l}$ \\
\hline $\mathrm{NaOH}$ & $1.0 \mathrm{ml}$ & $1.0 \mathrm{ml}$ \\
\hline $\mathrm{Na}_{2} \mathrm{CO}_{3}$ & $1.0 \mathrm{ml}$ & $1.0 \mathrm{ml}$ \\
\hline Sodium Potassium Tartrate & $200 \mu \mathrm{l}$ & $200 \mu \mathrm{l}$ \\
\hline Incubate at $37^{\circ} \mathrm{C}$ for $15 \mathrm{minutes}$ \\
\hline Folin-Ciocalteau phenol & $0.5 \mathrm{ml}$ & $0.5 \mathrm{ml}$ \\
\hline Incubate at $37^{\circ} \mathrm{C}$ (dark) for $20 \mathrm{minutes}$ \\
\hline \multicolumn{3}{|l|}{ Optical density read at $640 \mathrm{~nm}$} \\
\hline
\end{tabular}

Optimization of culture conditions for maximum protease production Different media composition

Cultivations were performed at different media composition with $4 \%$ of inoculum at $37^{\circ} \mathrm{C}$ for $1-5$ days $(200 \mathrm{rpm})$ in order to study the maximum production of enzyme [11].

1. Wheat flour $(1 \% \mathrm{w} / \mathrm{v})$; Skim milk powder $(1 \%$ w/v); $\mathrm{NaCl}(0.5 \% \mathrm{w} / \mathrm{v})$

2. Starch $(1 \% \mathrm{w} / \mathrm{v})$; Skim milk powder $(1 \% \mathrm{w} / \mathrm{v})$; $\mathrm{NaCl}(0.5 \% \mathrm{w} / \mathrm{v})$

3. Maltose $(1 \% \mathrm{w} / \mathrm{v})$; Skim milk powder $(1 \%$ $\mathrm{w} / \mathrm{v}) ; \mathrm{NaCl}(0.5 \% \mathrm{w} / \mathrm{v})$

4. Basal media: Glucose $(1 \%$ w/v); Skim milk powder $(1 \% \quad \mathrm{w} / \mathrm{v}) ; \quad \mathrm{KH}_{2} \mathrm{PO}_{4} \quad(0.5 \quad \% \mathrm{w} / \mathrm{v})$; $\mathrm{K}_{2} \mathrm{HPO}_{4}(0.5 \% \mathrm{w} / \mathrm{v}) ; \mathrm{CaCl}_{2}(0.5 \% \mathrm{w} / \mathrm{v})$

The culture was centrifuged at $10000 \mathrm{rpm}$ for $10 \mathrm{~min}$ at $4^{0} \mathrm{C}$ and the supernatant was used for the estimation of protease activity.

\section{Inoculum size and agitation speed}

The optimised Wheat Skim (WS) milk powder media was inoculated in a different concentration of preinoculum of $2,4,6,8$ and $10 \%(\mathrm{v} / \mathrm{v})$ then incubated at $37^{\circ} \mathrm{C}$ for $1-5$ days $(200 \mathrm{rpm})$. The optimum inoculum size determined from this study was used to inoculate fresh WS media to test the agitation speed effect at $30^{\circ} \mathrm{C}$, $25^{\circ} \mathrm{C}$ and $37^{\circ} \mathrm{C}$ respectively $120,140,200 \mathrm{rpm}$ for $1-4$ days.

\section{Effect of pH on activity and stability}

The crude enzyme activity was optimized in Wheat skim milk medium (WS) and 6\% inoculum at varying $\mathrm{pHs}$ ranging from 4 to 10 by using $0.1 \mathrm{M}$ acetate, $0.1 \mathrm{M}$ phosphate and $0.1 \mathrm{M}$ carbonate buffers. The stability was checked at particular time interval. For acidic $\mathrm{pH}$, haemoglobin was used as a substrate for the enzyme instead of casein in the protease assay.

\section{Effect of temperature on activity and stability}

The influence of temperature on the activity of the enzyme was determined at temperatures range from $25^{\circ} \mathrm{C}$ to $70^{\circ} \mathrm{C}$. Aliquots of the enzyme solution in $0.1 \mathrm{M}$ Carbonate buffer ( $\mathrm{pH}$ 9.2) were exposed to temperatures ranging from $25^{\circ} \mathrm{C}$ to $70^{\circ} \mathrm{C}$ for 1 and 2 hours. The residual protease activity of the heat-treated enzyme samples was determined.

\section{Effect of additives and metal ions}

Protease enzyme was investigated by the addition of various additives like SDS $(0.1 \mathrm{M})$, Tween 80 (1\% v/v), Triton-X 100 (1\% v/v), Urea (0.1 M), Cysteine $(5 \mathrm{mM})$, Calcium chloride $(0.1 \mathrm{M})$ and Sodium azide $(0.05 \%)$ [12]. The effect of different metal ions $\left(\mathrm{K}^{+}, \mathrm{Ca}^{2+}, \mathrm{Mg}^{2+}, \mathrm{NH}_{4}^{+}, \mathrm{Li}^{+}, \mathrm{Hg}^{2+}\right.$ and $\mathrm{Ni}^{2+}$ ) on protease activity was determined by the addition of the corresponding chlorides of the metal ions at a final concentration of $0.1 \mathrm{M}$ to the reaction mixture, and 
assayed for protease activity initially and after every 24 hours for 3 days [13].

\section{Scale-up studies and partial purification}

Protease enzyme production was carried out in a $50 \mathrm{ml}$ of WS medium at $30^{\circ} \mathrm{C}$ in a shaking incubator $(140 \mathrm{rpm})$ with $6 \%$ inoculum. The culture was removed after 72 hours and centrifuged at $10000 \mathrm{rpm}$ for $10 \mathrm{~min}$ at $40^{\circ} \mathrm{C}$ using Beckman- Coulter Centrifuge. The cell free supernatant was used as the crude enzyme for further studies. The extra cellular protease was treated with ammonium sulphate from $0-90 \%, 20-40 \%$ and $60-80 \%$ saturation. The crude enzyme extracts were subjected to SDS-PAGE on $12 \%$ resolving gel. $50 \mu 1$ of enzyme was loaded with $100 \mathrm{KD}$ reference marker and electrophoresed at $100 \mathrm{~V}$ [14].

\section{Application studies}

Retrieved protease crude enzyme was applied in a dehairing process. Goat's skin was cut into $15 \mathrm{~cm}^{2}$ pieces. This sample was incubated with the crude enzyme $(25 \mathrm{ml})$ at $120 \mathrm{rpm}$ shaking conditions at $30^{\circ} \mathrm{C}$. The skin was checked for depilation of hair after 24 hours.

\section{RESULT AND DISCUSSION \\ Isolation of proteolytic bacteria}

In situ protease production was demonstrated by the clearing of opaque milk proteins in the area surrounding isolated colonies growing on the surface. Depending upon the zone of clearance, the high yield protease strains were selected for further experimental studies. The proteolytic activity was assayed using skim milk agar and expressed as diameter of clear zone in $\mathrm{cm}$. White colony exhibited the highest proteolytic activity with a clear zone diameter of $1.3 \mathrm{~cm}$ followed by Yellow colony with zone of $0.7 \mathrm{~cm}$ (Figure-1). As the white colonies showed higher proteolytic activity than yellow colonies, they were selected for further studies.

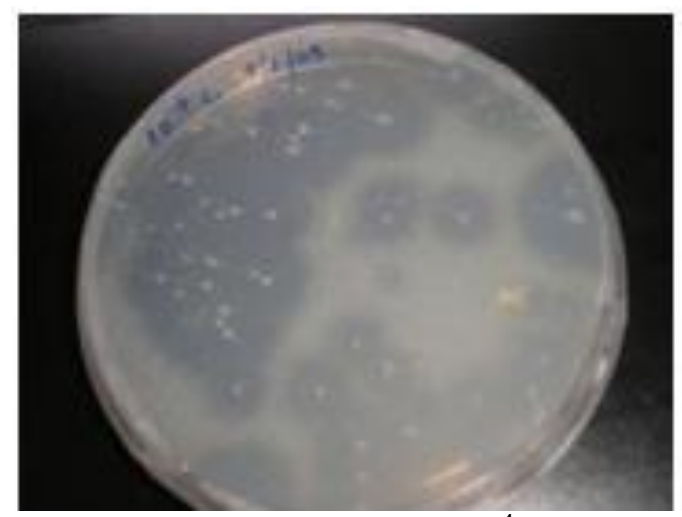

Fig-1a: Skim milk agar plate at $10^{-4}$ dilution

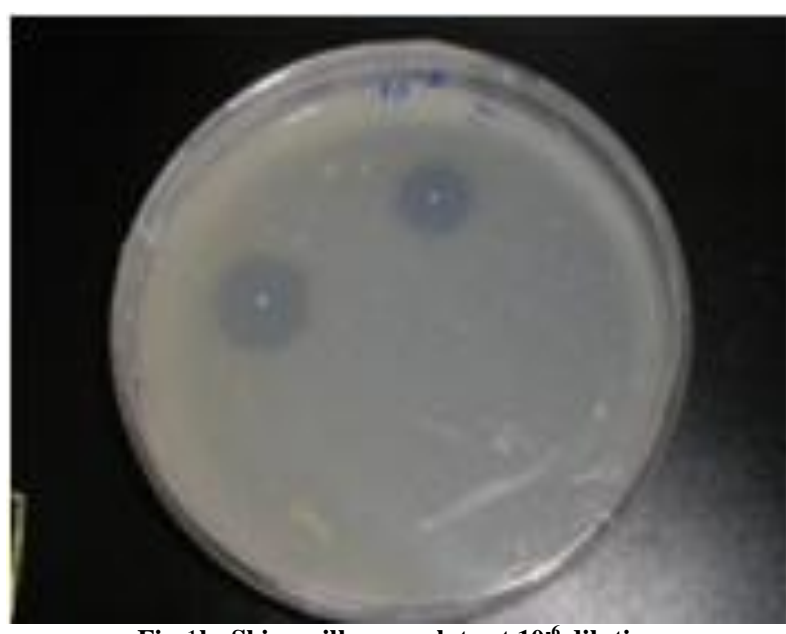

Fig-1b: Skim milk agar plate at $10^{-6}$ dilution

\section{Characterisation of the isolate}

The bacterial isolate might be Pseudomonas like organism. The results of the biochemical tests are as follows:

\begin{tabular}{|l|l|}
\hline Test Name & Results \\
\hline Gram's staining & -ve \\
\hline Indole test & -ve \\
\hline Methyl red test & -ve \\
\hline Voges-Proskauer test & -ve \\
\hline Citrate Utilization test & +ve \\
\hline Triple Sugar Iron test & Alkaline slant acid butt \\
\hline Oxidase test & $+\mathrm{ve}$ \\
\hline Catalase test & $+\mathrm{ve}$ \\
\hline Urease test & $+\mathrm{ve}$ \\
\hline Nitrate test & $+\mathrm{ve}$ \\
\hline
\end{tabular}

\section{Medium Optimization}

An attempt was made for optimising the medium to facilitate the growth of the organism. The nitrogen source (Skim Milk) and inorganic salt source $(\mathrm{NaCl})$ were kept constant, while four different carbon sources (Wheat flour, Starch, Maltose, Basal Medium) were changed to find the maximum activity of the enzyme. Of these medium containing Wheat Flour as carbon source gave the maximum activity on third day of incubation. The activity of the crude enzyme was found to be $180.30 \mathrm{mg}$ tyrosine release per $\mathrm{ml}$ per minute. The results in detail are presented in Figure-2. Production of protease is highly dependent on the ratio of carbon and nitrogen sources. Since Wheat flour is an inexpensive and readily available substrate, it was to be a possible candidate for the cost effective production of an extracellular protease when used as culture medium ingredient. 


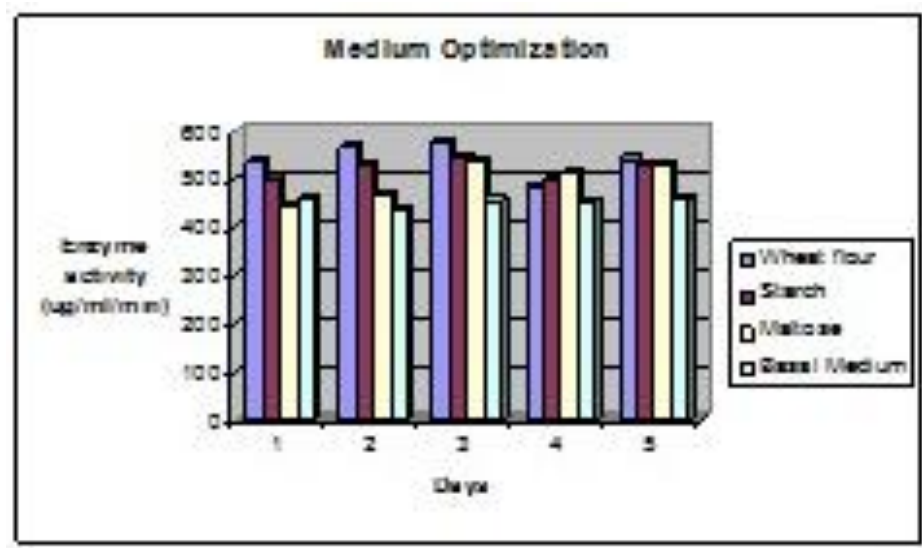

Fig-2: Media Optimization

\section{Optimization of Inoculum concentration}

Following medium optimization, the effect of inoculum concentration on the enzyme production was studied and the results are presented in Figure-3. In this study, varied inoculum concentration $(2 \% \mathrm{v} / \mathrm{v}, 4 \% \mathrm{v} / \mathrm{v}$,
$6 \% \mathrm{v} / \mathrm{v}, 8 \% \mathrm{v} / \mathrm{v}$ and $10 \% \mathrm{v} / \mathrm{v}$ ) was used in production medium. The maximum activity, $654.105 \mathrm{mg} / \mathrm{ml} / \mathrm{min}$, was observed with $6 \%$ inoculum concentration on the third day of incubation.

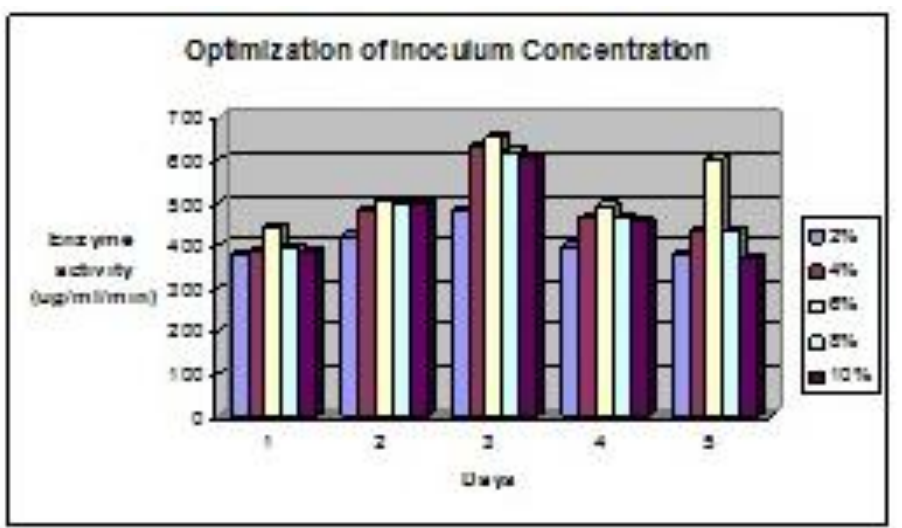

Fig-3: Inoculum concentration optimization

\section{Optimization of Agitation Speed}

The effect of the agitation speed on the protease enzyme synthesis was determined, by inoculating $6 \mathrm{ml}$ of pre-inoculum into $100 \mathrm{ml}$ of WS media and incubated at 120,140 and $200 \mathrm{rpm}$. Based on the protease activities, $140 \mathrm{rpm}$ was determined to be the optimum agitation. This could be explained besides the characteristics of the strain, with a better oxygen and nutrient transfer rate at this speed, promoting more cell growth. It was obvious from the given data, that the strain does not require very high agitation speed for enzyme synthesis, probably due to the decreased requirements for oxygen (Figure-4).

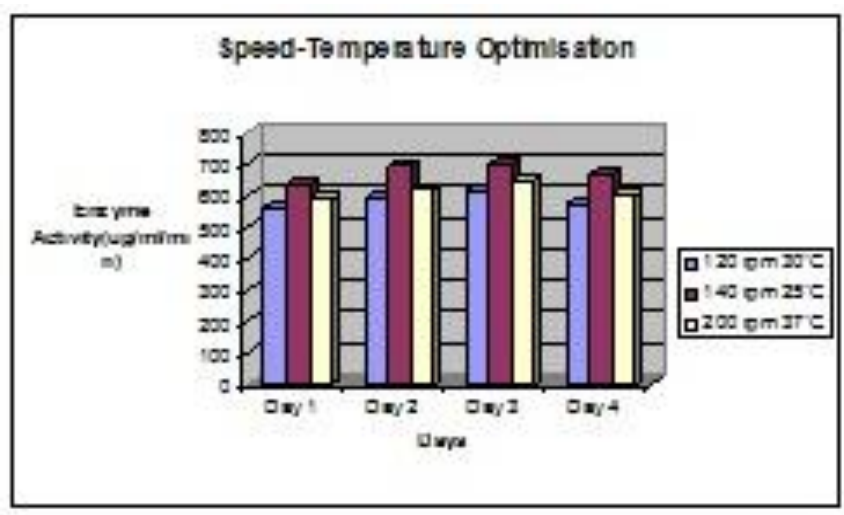

Fig-4: Optimization of agitation speed 


\section{pH Profile}

A pH range between 4.0 and 10.0 was used to study the effect of $\mathrm{pH}$ on protease activity. Optimum $\mathrm{pH}$ was found to be 9.0. Protease enzyme generally can be categorized into two groups with respect to their optimal $\mathrm{pH}$, neutral and alkaline proteases. The former exhibit optimal $\mathrm{pH}$ at 7.0 whereas the later have $\mathrm{pH}$ optima between 9-11.20. Therefore, the crude protease enzyme belongs to the alkaline group since they had optimal $\mathrm{pH}$ at 9 (Figure-5a). The protease activity measured as a function of time showed a decrease of about $20 \%$ and $30 \%$ of its original activity at the end of 1 and 2 hours respectively (Figure-5b).

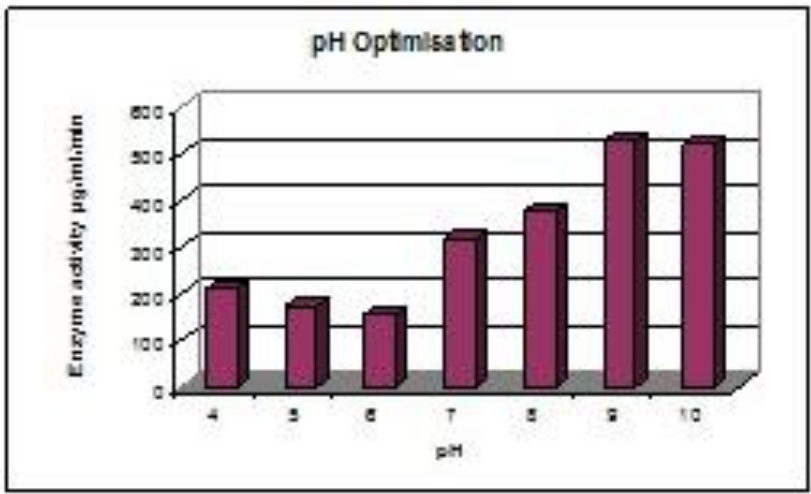

Fig-5a: Optimisation of pH

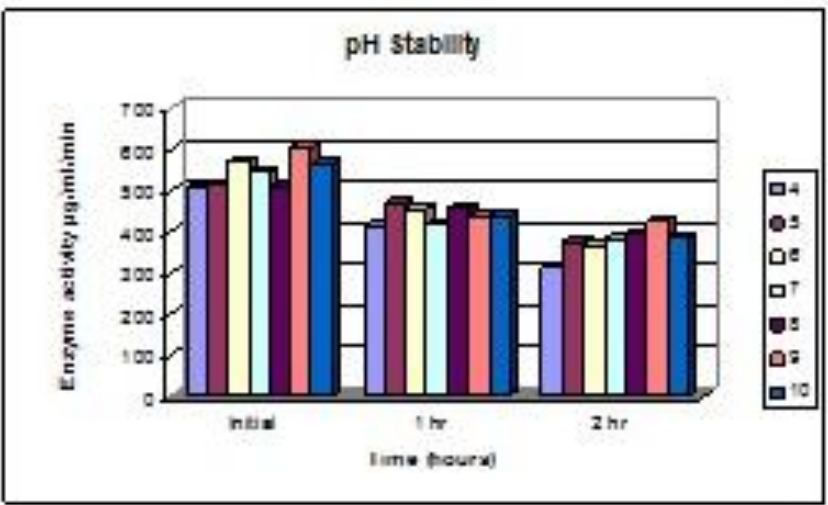

Fig-5b: Stability of pH

\section{Temperature Profile}

The protease activities were assayed at different temperatures ranging from $25^{\circ} \mathrm{C}-70^{\circ} \mathrm{C}$ at a constant $\mathrm{pH}$ of 9.2. Enzyme activity increased with temperature within the range of $25^{\circ} \mathrm{C}$ to $40^{\circ} \mathrm{C}$. A reduction in enzyme activity was observed at values above $40^{\circ} \mathrm{C}$ (Figure-6a).
The optimum temperature of this protease was $40^{\circ} \mathrm{C}$ which was similar to that described for Bacillus protease. Thermostability profile indicated that the enzyme was stable at $40^{\circ} \mathrm{C}$ for 1 hour while at $60^{\circ} \mathrm{C}$ and $70^{\circ} \mathrm{C}, 2 \%$ and $99 \%$, of the original activities were lost, Respectively (Figure-6b).

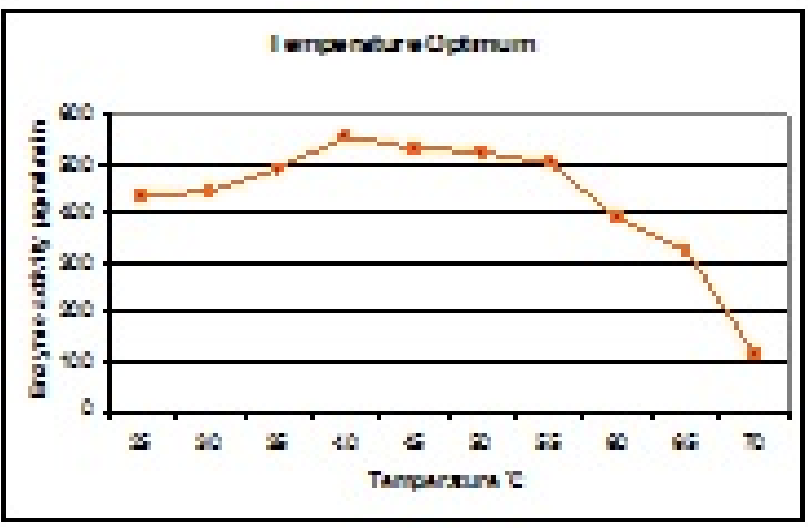

Fig-6a: Optimisation of temperature 


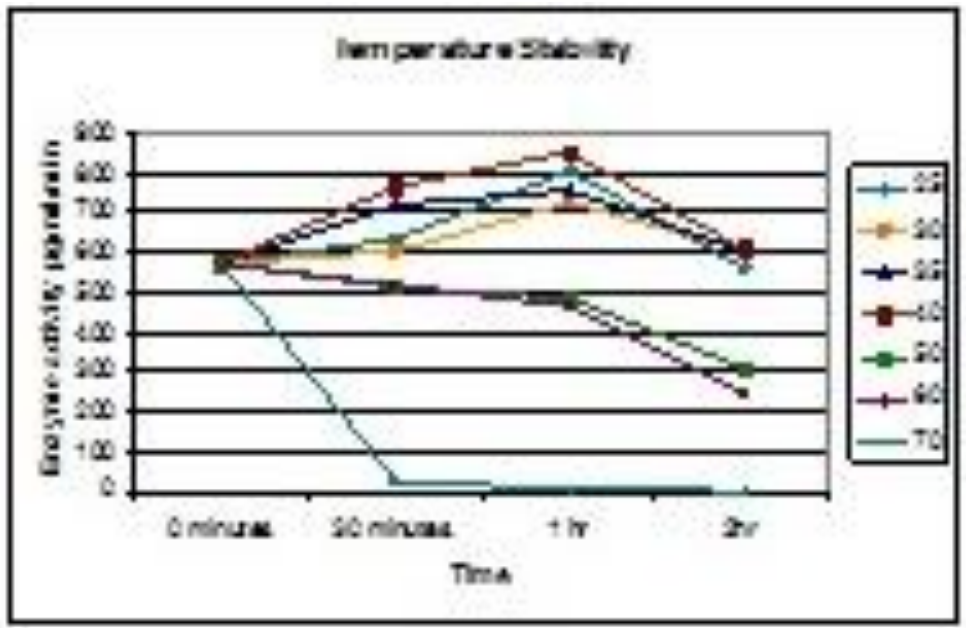

Fig-6b: Stability of temperature

\section{Partial purification}

Having optimised various parameters, the crude enzyme was subjected to 0-90\% Ammonium sulphate precipitation method. Later the method was carried out in series $(0-20 \%, 20-40 \%, 40-60 \%, 60-80 \%)$ as described. It is observed from the activity data that the crude enzyme seems to lose its activity during the process of precipitation. This may be due to aggregation of enzyme molecule due to high ionic strength. Moreover large portion of enzyme activity was also seemed to be left unprecipitated and hence was detected in the supernatant. Therefore, it is understood that the enzyme purification process applied in this study requires an alternative method.

\section{SDS-PAGE}

The enzyme precipitated by ammonium sulphate precipitation $(20-40 \%)$ was loaded into a SDS-PAGE (12\% resolving gel). A series of bands were observed indicating the presence of mixture of proteases. The apparent molecular weight of the enzyme as observed was in the range 68-97.4 KD [15].

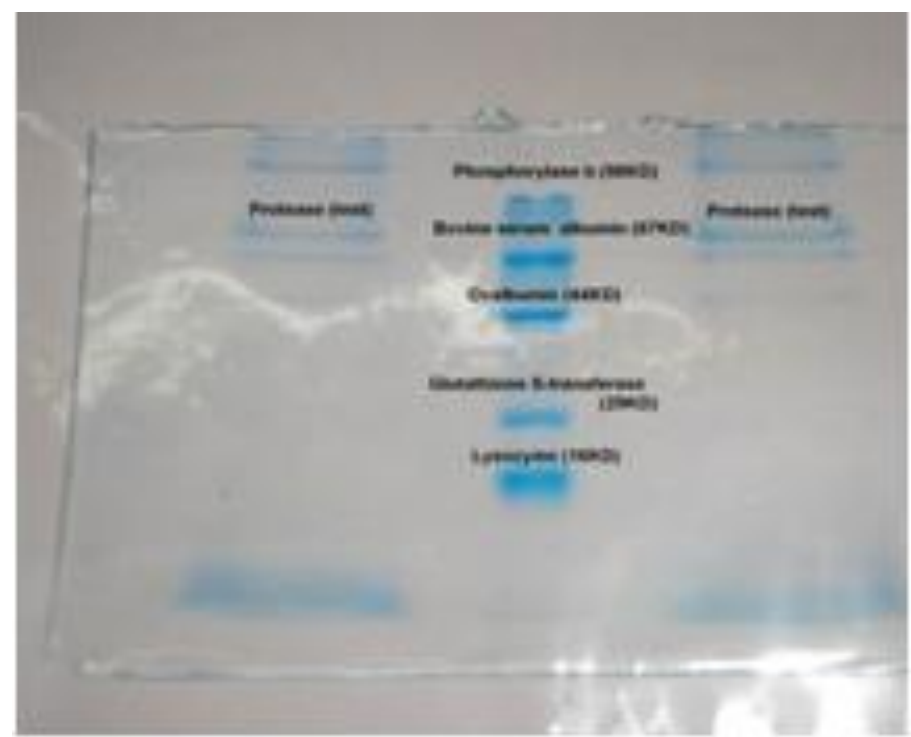

Fig-7: SDS PAGE: Lane1(Partially purified enzyme), Lane 2 ( From top to bottom) (Medium range protein marker- PPMWM GeNei ${ }^{\text {TM }}$ Phosphorylase b 98KD; Bovine Serum Albumin 67KD, Ovalbumin 44KD; Glutathione S-transferase 29KD; Lysozyme 16KD), Lane 3 (Partially purified enzyme)

\section{Effect of Additives}

Surfactants are amphiphilic molecules with polar headgroups (hydrophilic part) and hydrophobic tails. They can be anionic, cationic or nonionic according to the charge of the hydrophilic headgroups. The protease from Pseudomonas sp. showed stability and compatibility not only toward the non-ionic surfactants like Triton-X-100 but also toward strong anionic surfactant like SDS (Figure-8). 


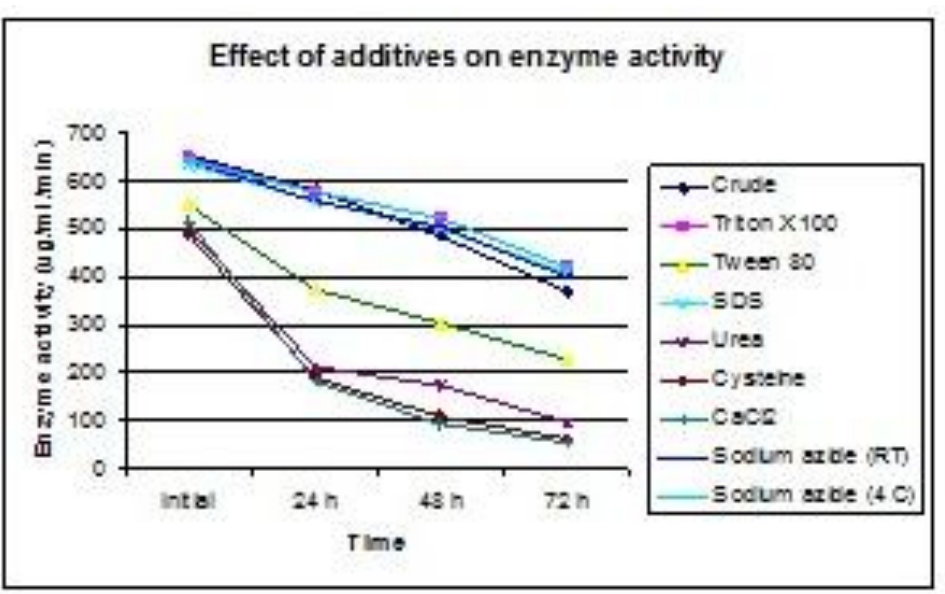

Fig-8: Effect of additives

\section{Effect of Metal Ions}

A strong inhibitory effect was observed in the presence of mercury. $\mathrm{Hg}^{2+}$ almost completely incubated the enzyme at $0.1 \mathrm{M}$ concentrations. Similar effects of $\mathrm{Hg}^{2+}$ on the activity of protease were also observed by Wellingta Cristina Almeida do Nascimento et al., [16]. The inhibitory of heavy metal ions is well documented in the literature. It is known that the ions mercury, cadmium and lead react with the protein thiol groups (converting them to mercaptides), as well as with histidine and tryptophan residues. Moreover, by action of silver and mercury, the disulphide bonds were found to be hydrolytically degraded. $\mathrm{Ni}^{2+}$ does not show any stabilising effect both initially and after incubation.

Remarkable enzyme stability was observed in the presence of $\mathrm{Ca}^{2+}$ and $\mathrm{Li}^{+}$initially. Whereas, $\mathrm{K}^{+}, \mathrm{Mg}^{2+}$ and $\mathrm{NH}^{4+}$ maintained a higher activity after 48 hours. These results suggest that these metal ions apparently played a vital role in maintaining the active conformation of the enzyme (Figure-9).

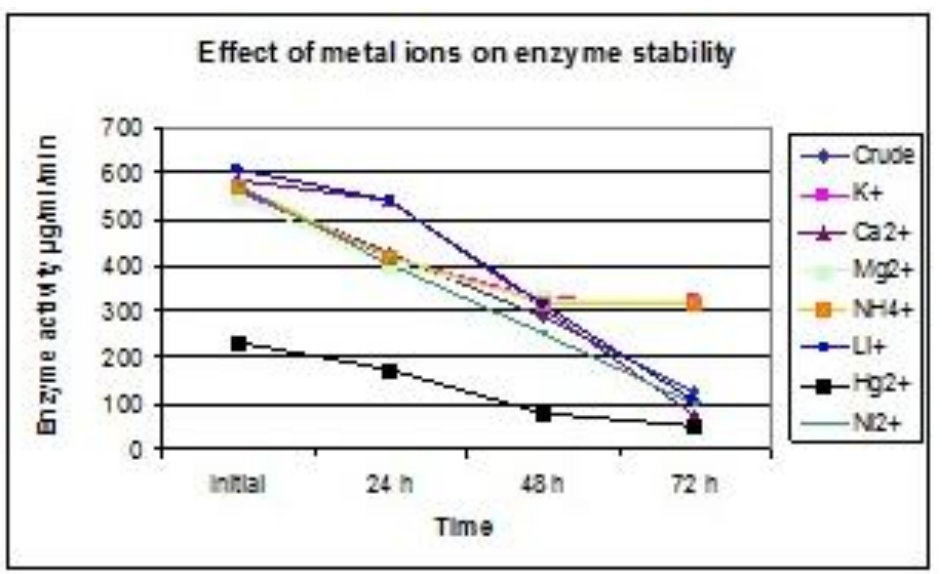

Fig-9: Effect of metal ions

\section{Applications}

Incubation of the protease with skin for dehairing showed that after 24 hours incubation of the enzyme with goat skin, hair was removed very easily (Figure 10a and 10b) when compared to the control in which the hair was not removed even by applying mechanical force using a forceps. As against traditional chemical methods enzymatic processes yield products of improved quality and reduce the use of hazardous and polluting chemicals. 
S. Vasantham \& S. Chithra., Sch Acad J Biosci, May., 2020; 8(5): 118-126

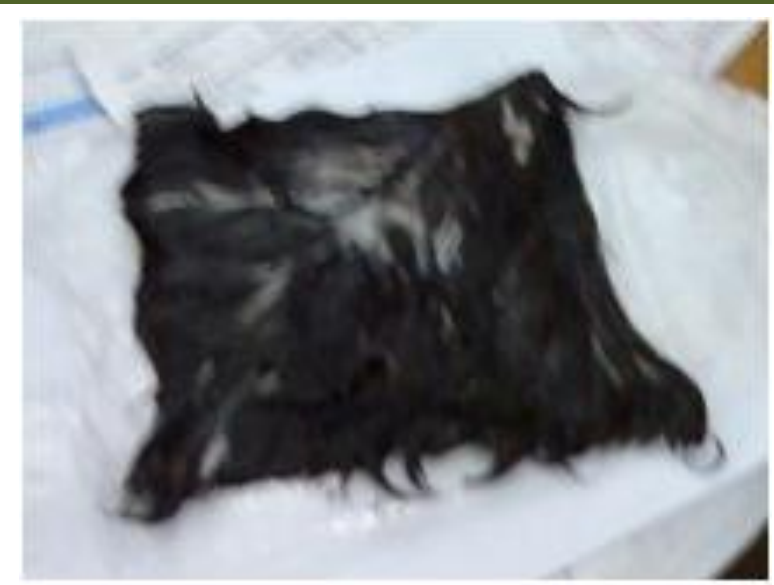

Fig-10a: Control

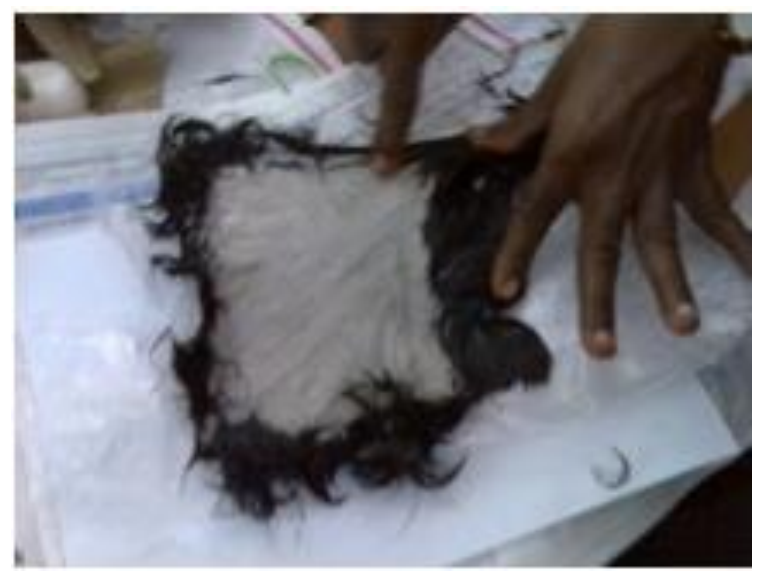

Fig-10b: Goat skin treated with crude enzyme

\section{CONCLUSION}

In commercial practice, the optimization of medium composition is done to balance between the various medium components, thus minimizing the amount of unutilized components at the end of the proteolytic activity. In the present study, various parameters of environmental and nutritional factors were tested. Research efforts have been directed mainly toward evaluating the effect of various carbon nutrients cost effect substrates on the yield of enzymes and optimization of environmental conditions and parameters such as $\mathrm{pH}$, temperature and agitation.

The enzyme showed optimum activity in alkaline $\mathrm{pH}$ range and moderate temperature range $(\mathrm{pH}$ 9.2 and $40^{\circ} \mathrm{C}$ ). However, the enzyme did not show reasonable stability in the presence of agents generally used to purify protein and enhance stability. This opens wide scope for further research to identify novel agents to increase the yield of this protease and improve its stability under normal conditions. The enzyme could dehair cattle skin indicating its potential application in Leather industry [17].

\section{ACKNOWLEDGEMENT}

Author thank Dr.C.Rose. Ph.D., Deputy Director and Head of the Department of Biotechnology,
C.L.R.I for allowing to complete this project work in the Department lab C.L.R.I.

\section{REFERENCE}

1. Paula MS, Mona Lisa AB, Carolina CC, Marcela F, Renata Paula CA, Damaris S, Yris MF, Edivaldo Ximenes FF, Adalberto PJ, Pérola OM. A biotechnology perspective of fungal proteases. Brazilian Journal of Microbiology. 2015; 46 (2): 337-346.

2. Arun KS, Vinay Sharma, Jyoti Saxena, Bindu Yadav, Afroz Alam, Anand Prakash. Optimization of protease production from bacteria isolated from soil. Applied Research Journal. 2015; 1(7): 388-394.

3. Cheng Zhou, Hongliang Qin, Xiujuan Chen, Yan Zhang, Yanfen Xue, Yanhe Ma. A novel alkaline protease from alkaliphilic Idiomarina sp. C9-1 with potential application for eco-friendly enzymatic dehairing in the leather industry. Scientific Reports. 2018; 8: 6467.

4. Kanupriya Miglani SA, Rajesh Kumar A, Surbhi Panwar B, Ashwani Kumar C. Microbial alkaline proteases: Optimization of production parameters and their properties. Journal of Genetic Engineering and Biotechnology. 2017; 15: 115126.

5. Abdul Razzaq, Sadia Shamsi, Arfan Ali, Qurban Ali, Muhammad Sajjad, Arif Malik, Muhammad Ashraf. Microbial Proteases Applications. Front. Bioeng. Biotechnol. 2019; 7: 110.

6. Palanisamy Thanikaivelan, Jonnalagadda RR, Balachandran UN, Thirumalachari Ramasami. Progress and recent trends in biotechnological methods for leather processing. TRENDS in Biotechnology. 2004; 22: (4).

7. Dhillon A, Sharma K, Rajulapati V, Goyal A. Proteolytic Enzymes. Current Developments in Biotechnology and Bioengineering: Production, Isolation and Purification of Industrial Products. 2016; 149- 165.

8. Asha B, Palaniswamy M. Optimization of alkaline protease production by Bacillus cereus FT 1 isolated from soil. Journal of Applied Pharmaceutical Science. 2018; 8(02): 119-127.

9. Pintubala K, Oscar N, Debananda SN. Optimization of Alkaline Protease Production by Alkaliphilic Bacillus sp. KW2 in Low Cost Medium using Statistical Approaches. Appli Micro Open Access. 2016; 2:3.

10. Ahmed AH, Mohamed K, Mohamed A. Molecular characterization of alkaline protease-coding gene from Bacillus licheniformis MK90 mutants with biofilm inhibitory activity. Egyptian Pharmaceutical Journal. 2019; 18: 419-433.

11. Maryam MT, Bahar S, Razie GB, Mansour M, Jamshid F. Optimization of Protease Production by Psychrotrophic Rheinheimera sp. with Response 
S. Vasantham \& S. Chithra., Sch Acad J Biosci, May., 2020; 8(5): 118-126

Surface Methodology. Applied food biotechnology. 2016; 3(4): 236-245.

12. Canan T, Hande G, Figen T. Optimization of a growth medium using a statistical approach for the production of an alkaline protease from a newly isolated Bacillus sp. L21. Process Biochemistry. 2006; 41: 659-665.

13. Folasade MO, Ayodele MF. Purification and partial characterization of serine alkaline metalloprotease from Bacillus brevis MWB-01. Bioresources and Bioprocessing. 2014; 1:8.

14. Kobayashi T, Hakamada Y, Hitomi J, Koike K, Ito S. Purification of alkaline proteases from a Bacillus strain and their possible interrelationship. Appl Microbiol Biotechnol. 1996; 45: 63-71.
15. Nilegaonkar SS, Zambare VP, Kanekar PP, Dhakephalkar PK, Sarnaik SS. Production and partial characterization of dehairing protease from Bacillus cereus MCM B-326. Bioresource Technology. 2007; 98: 1238-1245.

16. Wellingta Cristina AN, Meire Lelis LM. Production and Properties of An Extracellular Protease From Thermophilic Bacillus Sp. Brazilian Journal of Microbiology. 2004; 35: 91-96.

17. Nilegaonkar SS, Zambare VP, Kanekar PP. A novel alkaline protease from alkaliphilic Idiomarina sp. C9-1 with potential application for eco-friendly enzymatic dehairing in the leather industry. Scientific Reports. 2018; 8: 16467. 